\title{
Congenitalis dysmorphiával, kamrai aritmiával és periodikus paralízissel járó ioncsatorna- betegség: Andersen-Tawil-szindróma
}

\author{
Borbás János', Erdős Barbara', Katona Márta², Környei László3, Ördög Balázs ${ }^{4}$
}

\author{
1'Szegedi Tudományegyetem, II. sz. Belgyógyászati Klinika és Kardiológiai Központ, Szeged \\ ${ }^{2}$ Szegedi Tudományegyetem, Gyermekgyógyászati Klinika, Szeged \\ ${ }^{3}$ Gottsegen György Országos Kardiológiai Intézet, Budapest \\ ${ }^{4}$ Szegedi Tudományegyetem, Farmakológiai és Farmakoterápiai Intézet, Szeged
}

Levelezési cím: Dr. Borbás János

Szegedi Tudományegyetem, II. sz. Belgyógyászati Klinika és Kardiológiai Központ

6725 Szeged, Semmelweis u. 8. E-mail: borbas.janos@med.u-szeged.hu

\begin{abstract}
Az Andersen-Tawil-szindróma (ATS) a hosszú QT-szindróma egyik altípusaként (LQT7) definiált ritka ioncsatorna-betegség, amelyet periodikus paralizis, kamrai aritmiák és fejlődési rendellenességek triásza jellemez. Az ATS autoszomális domináns módon öröklődik és a legtöbb esetben a KCNJ2-génben előforduló mutációk okozzák. A KCNJ2-gén a Kir2.1-es fehérjét kódolja, amely a fő pórusformáló alegység a befelé egyenirányító $\mathrm{K}^{+}$-csatornában, amelyen keresztül az $\mathrm{I}_{\mathrm{K} 1}$-transzmembrán káliumáram folyik. Az ATS-betegekben kialakuló kardiális érintettséget enyhe QT-megnyúlás, prominens U-hullámok, frekvens kamrai extrasytolia és típusos esetben bidirekcionális kamrai tachycardia jellemzi. Az ATS nonkardiális tünetei közé fejlődési rendellenességek, mint pl. koponya-, arc- és vázizomzat-elváltozások (alacsonyan ülö fülek, mélyen ülő szemek, hipertelorizmus, széles homlok, széles orrhát, micrognathia, alacsony termet) tartoznak. Gyakori nonkardiális tünet a periodikus paralízis, de előfordulhat kognitív képességek romlása is.

Az ATS diagnózisát a típusos tünetek megléte alapján és az azt kiegészítő genetikai vizsgálattal lehet felállítani. A betegség kezelésében a szerteágazó szervi érintettsége miatt alapvető a multidiszciplináris együttműködés. A káliumszint „magas normál” tartományban tartása a periodikus paralízis és ritmuszavarok kialakulásának esélyét is csökkenti. A periódikus paralízis tüneteinek enyhítésére karboanhidráz-bénítót lehet alkalmazni. A kamrai ritmuszavarok csökkentésére a flecainid terápia tűnik a leghatásosabbnak, amely a tachycardia indukálta cardiomyopathia megelőzésében is hatásos lehet. A nagy aritmiateher ellenére ICD-implantáció egyértelműen csak abortált szívhalál után szekunder prevenciós célzattal javasolt, míg gyógyszeres terápiára refrakter, panaszokat okozó ritmuszavarok esetén vagy a balkamra-funkció csökkenésével járó esetekben gondos megfontolás után merül fel ICD-implantáció.
\end{abstract}

Kulcsszavak: Andersen-Tawil-szindróma, periodikus paralízis, KCNJ2-gén

Ion channel disease associated with congeintal dysmorphies, ventricular arrhytmias and periodic paralysis: Andersen-Tawil syndrome

Andersen-Tawil syndrome (ATS) is a rare and unique genetic disorder considered as one of the subtypes of long QT syndrome (LQT7) and characterized by a triad of clinical manifestations including periodic paralysis, ventricular arrhythmias and dysmorphic features. From the genetic and molecular point of view, ATS is inherited as an autosomal dominant trait and is caused by mutations affecting the KCNJ2 gene. KCNJ2 gene encodes the Kir2.1 protein, which is the main pore-forming unit of the inward rectifier potassium channel conducting the $I_{\mathrm{K} 1}$ ionic current.

Cardiac involvement in ATS includes typical ECG manifestations represented by mild QT prolongation, prominent $U$ waves, premature ventricular beats, as well as bidirectional ventricular tachycardia. Non-cardiac manifestation of ATS include cranial, facial and skeletal muscle anomalies such as low-set ears, deep-set eyes, hypertelorism, broad forehead, broad nasal bridge, micrognathia, as well as short stature. Periodic paralysis is a frequent non-cardiac symptom, and sometimes cognitive abnormalities may occur. The diagnosis of the disease is based on the identification of typical signs of ATS which is complemented by genetic testing. Due to the widespread organ manifestation of the disease treatment requires multidisciplinary approach. Keeping potassium level in the "high normal" range reduces the occurrence of periodic paralysis and arrhythmias. Carboanhydrase inhibitors may reduce the symptoms of periodic paralysis. Flecainide therapy seems to be the most effective for reducing the arrhythmia burden of the disease and may prevent tachycardia induced cardiomyopathy. Despite of the pronounced arrhythmia burden implantable cardioverter defibrillator (ICD) is indicated clearly only as secondary prevention after aborted sudden cardiac death. Symptomatic disease refractory of drug treatment or development of left ventricular dysfunction may also indicate ICD implantation after careful consideration.

Keywords: Andersen-Tawil syndrome, periodic paralysis, KCNJ2 gene 


\section{Bevezetés}

Az Andersen-Tawil-szindróma (ATS) a monogénes, Mendeli öröklődést mutató familiáris kardiológiai kórképek közül (hypertrophiás cardiomyopathia [1, 2, 3], Danon-betegség [4], Fabry-betegség [5], stb.) a familiáris ioncsatorna-betegségek (hosszú QT-szindróma [6], Timothy-szindróma [7], familiáris bradycardia [8], stb.) közé tartozó ritka kórkép. Bár az EKG korrigált QT-szakaszának megnyúlása nem típusosan jellemzi a betegséget, mégis a hosszú QT-szindróma egyik altípusaként (LQT7) definiálják.

Az ATS ritka kórkép, amelyet periodikus paralízis, kamrai aritmiák és fejlődési rendellenességek triásza jellemez. A szindrómát elsőként 1963-ban Klein és munkatársai írták le, mikor is a periodikusan fennálló paralízis és a kamrai extraszisztolék között fennálló összefüggésről közölték megfigyeléseiket (9). Az 1970-es évek elején Ellen Damgaard Andersen és munkatársai átfogó vizsgálataik után már pontosabban körvonalazták a betegség mai értelemben vett klasszikus, fenotípusosan jellemző tünettriászát (10). 1994-töl Tawil és munkatársai már Andersen-szindrómaként nevezték kutatásaik során a betegséget, amelynek tovább pontosították klinikai ismérveit, így egyértelmübbé téve ezzel a szindróma diagnosztikai kritériumait (11). Ezen egymásra épülő kutatások nyomán 2003-tól széles körben is elfogadottá vált az Andersen-Tawil-szindróma elnevezés (12). A betegség pontos prevalenciája nem ismert, hozzávetölegesen becsült értéke 1/1 000000 (13). A kórkép Magyarországon is ismert, az első genetikailag igazolt eset leírását munkacsoportunk közölte (20).

\section{Molekuláris genetika és patomechanzimus}

Az Andersen-Tawil-szindrómának sporadikusan elöforduló és örökletes formája is létezik, utóbbi autoszomális domináns öröklődésmenetet követ (14). Ezen esetekben a hibás, mutáció által érintett gén a $K C N J 2$ nevü gén, amely alapvetően az izomrostokban azonosítható, befelé irányító, egyenirányú $\mathrm{K}^{+}$-ioncsatorna pórusformáló alegységét, a Kir2.1 proteint kódolja (15). A KCNJ2-gén föleg a vázizomzat és a szívizom izomsejtjeiben expresszálódik, szívizomban is leginkább a kamrák területén jelentős a génexpresszió foka, a pitvarok területén kevésbé meghatározó a jelenléte (16). A KCNJ2-gén mutációit az ATS-betegek mintegy 6070\%-ában lehet kimutatni, ezen genotípussal rendelkező betegek az ATS 1-es altípusát alkotják. Minden más eredetű ATS-esetet ATS 2-es alcsoportként azonosítunk (17).

A KCNJ2-gén által kódolt fehérje egy négy alegységből álló tetramer szerkezetü kálium-ioncsatorna, a Kir2.1 protein. Térbeli struktúráját tekintve a Kir2.1 protein transzmembrán részét két alfa-hélix alkotja, amelyeket egy pórust formáló hurok köt össze $(18,19)$ (1. ábra). Ez alapvetően egy befelé egyenirányító káliumion-csatorna protein, amely az izomsejt-aktiváció akciós potenciáljának kialakulása és lecsengése során az $\mathrm{I}_{\mathrm{K} 1}$-repolarizáció terminális fázisáért felelős káliumion-áramlásban játszik fontos szerepet a szívizomban és a harántcsíkolt izomzatban egyaránt.

A KCNJ2-génnek mintegy 74 mutációja ismert, amelyek típusosan missense és nonsense mutációk, ritkában mikrodeléciók (20). A mutáns fehérjék többféle patomechanizmus révén változtathatják meg a csatorna működését. A KCNJ2-gént érintő mutációk mintegy felénél a csatorna azon részei károsodnak, amik kiemelten fontosak lennének a másodlagos hírvivő molekula, a foszfatidil-4,5-difoszfáttal (PIP2) való interakcióban a jelátvitel során (12). Kulcsfontosságúak továbbá a Kir2.1 pórusát formáló hurkot érintő KCNJ2-mutációk, mivel a pórusformáló hurok központi szerepű a csatorna funkcionalitásának kialakításában és fenntartásában. A mutációk további következménye lehet a fehérjék érése, valamint feltekeredése kapcsán létrejövő eltérések (18).

$A z I_{K 1}$-áram a legjelentősebb meghatározója a nyugalmi membránpotenciálnak, amelyet a Kir2.x család állít elő. A gént érintő mutációk jellegzetes "loss of function" mutációk, amelyek domináns negatív hatással vannak a csatorna müködésére (20). Az $I_{k 1}$-áram csökkenése folyamatos kamrai aktivitáshoz és a QT-szakasz megnyúlásához vezet $(20,21)$. A csökkent $I_{K 1}$-áram jellemzően kevésbé negatív membránpotenciált okozna, és ily módon vezetne ellentétes folyamathoz, de mindeközben a depolarizáció következtében változik az SCN5A-gén által kódolt nátriumion-csatornák nagy részének aktivitása is. Ennek következménye a csökkent membrán-ingerelhetőség, amely magyarázza az ATSre jellemző periódikus paralízist és izomgyengeséget. A beáramló nátrium „window” current továbbra is aktív, amely növeli a nátrium-kálium-pumpa aktivitását, ezáltal előidézve a kálium nagyfokú beáramlását is, így magyarázatot szolgáltat a betegekben előforduló hypokalaemiára.

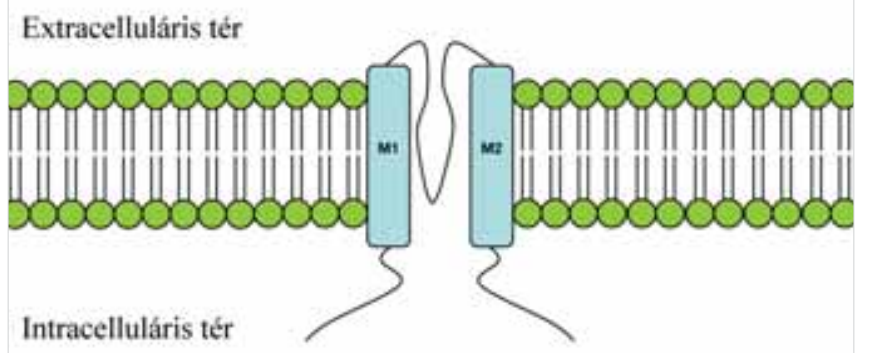

1. ÁBRA. A befelé irányító $\mathrm{K}^{+}$-csatornák (inwardly rectifyer, Kir) sematikus szerkezete. Az alegység két transzmembrán részből (M1 és M2) és a köztük lévő pórusformáló hurokból (P) épül fel. A csatorna amino- és karboxi terminusa intracellulárisan helyezkedik el 


\section{Klinikai megjelenés}

Az ATS tüneteinek megjelenése széles spektrumon mozog, a tünetek akár egy genetikailag azonos módon érintett családon belül is igen kifejezett, egyes esetekben egészen extrém fokú diverzitást mutathatnak.

\section{Nonkardiális manifesztációk \\ Periódikus paralízis}

A mindennapi élet során a paralitikus tünetek befolyásolják a betegek életminőségét a leginkább, így leggyakrabban ezen szimptómák nyomán kerül felismerésre a betegek nagy része. Hirtelen kezdődő jelleggel, néhány perctöl akár néhány napig változó intervallumra is kiterjedhet a paralízis, amely normo-, hypo- és hyperkalaemia mellett egyaránt kialakulhat, bár hypokalaemia alatt az említett periódusok száma és időtartama megnövekszik.

Időbeliség szempontjából is jellemzően a paralitikus tünetek jelennek meg legkorábbi életkorban $(10,22)$. Fontos és figyelmet felhívó klinikai tünetek a gyermek pár hónapos korától felbukkanhatnak bármikor az élet első, esetlegesen második évtizedével bezárólagosan, majd ezeket követi a kardiális tünetek pár éven belüli manifesztációja. Feltehetően triggereli a paralitikus-domináns időszakok megszaporodását az akut fizikai vagy mentális stresszhelyzet, de kedvezhet kialakulásának a kimerítő edzések utáni nyugalmi állapot, esetleg a környezeti hőmérséklet csökkenése (22). Egyes Andersen-Tawil-szindrómás betegek vizsgálata során egyes betegek atrófiás izomelváltozásait is megfigyelték (23).

\section{Congenitalis dysmorphiák}

Jellemzően fiatal életkorban válnak szembetünővé a szkeletális fejlődési anomáliák, scoliosis, a végtagokon clinodactylia és syndactylia, a kor elörehaladtával a testméret és súly elmaradása, a craniofacialis anomáliák, mint a hipertelorizmus, széles orrnyereg, mandibuláris hipoplázia, bilaterális ptosis, vékony haj és fogfejlődési malformációk, mandibularis és maxillaris hypoplasia $(9,10,12,13)$ (2. ábra).

\section{Neurológiai és neurokognitív vonatkozások}

KCNJ2 G300D-mutációt hordozó Andersen-Tawilszindrómás gyermekeknél több ízben tapasztaltak enyhe tanulási akadályozottságot, valamint nehezítettséget memóriafeladatokban és az olyan végrehajtó funkciók kivitelezésében, mint a tervezés, érvelés és a problémamegoldás. Mindezek mellett gyakoriak a betegeknél a hangulati élet változó fokú zavarai, az enyhe hangulati labilitástól a major depresszióig bezárólag (24).

\section{Kardiális manifesztációk \\ EKG morfológiai jellegzetességek}

Az EKG-n megfigyelhető eltérések a leggyakoribb és leginkább figyelmet felkeltő eltérések ATS-ben. Egyes

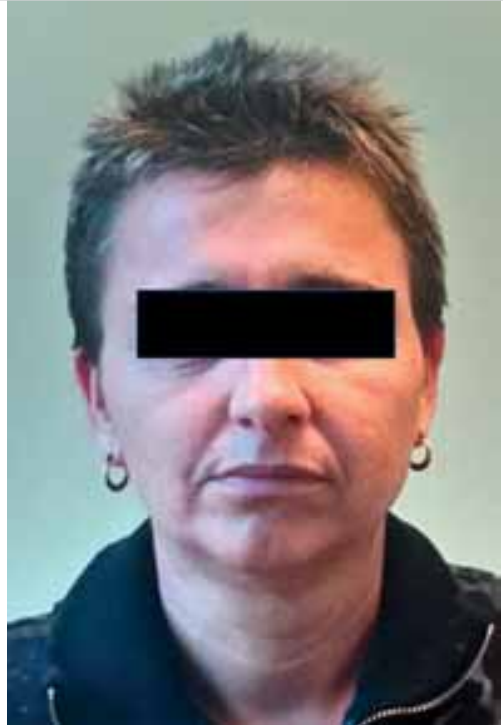

2. ÁBRA. Andersen-Tawil-szindrómában megfigyelhető craniofaciális eltérések: alacsonyan ülö fülek, szélesen ülő szemek, hipertelorizmus, széles homlok, széles orrhát, micrognathia és alacsony termet

betegekben enyhe $\mathrm{QT}_{\mathrm{c}}$-megnyúlás észlelhető, de a $\mathrm{QU}_{\mathrm{c}}$-tartam jelentős megnyúlása és a kifejezett $U$-hullámok jelenléte a legjellemzőbb. Az U-hullámok szélesek és magasak, leginkább a precordiális V2-3-elvezetésekben $(25,26)$ (3. ábra, A panel).

\section{Ritmuszavarok}

Az ATS-ben megfigyelhető aritmiák között a gyakori kamrai extraszisztolék, bidirekcionális coupletek és polimorf kamrai tachycardiák (VT) a legjellemzőbbek (3. ábra $B$ panel), amelyek akár tartósak, akár nem tartósak lehetnek (25). Típusos esetben a kamrai ektópiás ütések és a VT bidirekcionális és nem tartós jellegü, és a VT relatíve lassú, $\leq 150 /$ min frekvenciával. Bár a VT nem gyors és általában jól tolerált, az ES- és VT-epizódok mennyisége és tartama gyakran nagy, és a többi incessant tachycardiához hasonlóan tachycardia-indukált cardiomyopathiához vezethet. A KCNJ2-gén három p.Arg218Trp-mutáció hordozójából kettőben azonosítottak dilatatív cardiomyopathiát (29) míg egy p.Arg67Trp-mutációt hordozó betegben is azonosítottak dilatatív szívizom-elváltozást, amelyet flecainid terápia segítségével sikerült visszafordítani (30). Egy másik munkacsoport p.Leu222Ser novel mutáció kapcsán írt le cardiomyopathiát, amely esetben a bisoprolol jótékony hatásúnak bizonyult (31).

A bidirekcionális VT (a QRS tengelyének $180^{\circ}$-kal való változása ütésröl-ütésre) egy ritkán észlelt klinikai jelenség, amelyet ATS-ben, digitálisz toxicitás esetén és (27) és katecholaminerg polimorf kamrai tachycardiában (CPVT) (28) lehet megfigyelni. Az ATS- és CPVT-betegek elkülönítése klinikai szempontból nagyon fontos, hiszen a két betegség prognózisa és terápiája eltér egymástól. Genetikai vizsgálattal a CPVT-esetek leg- 


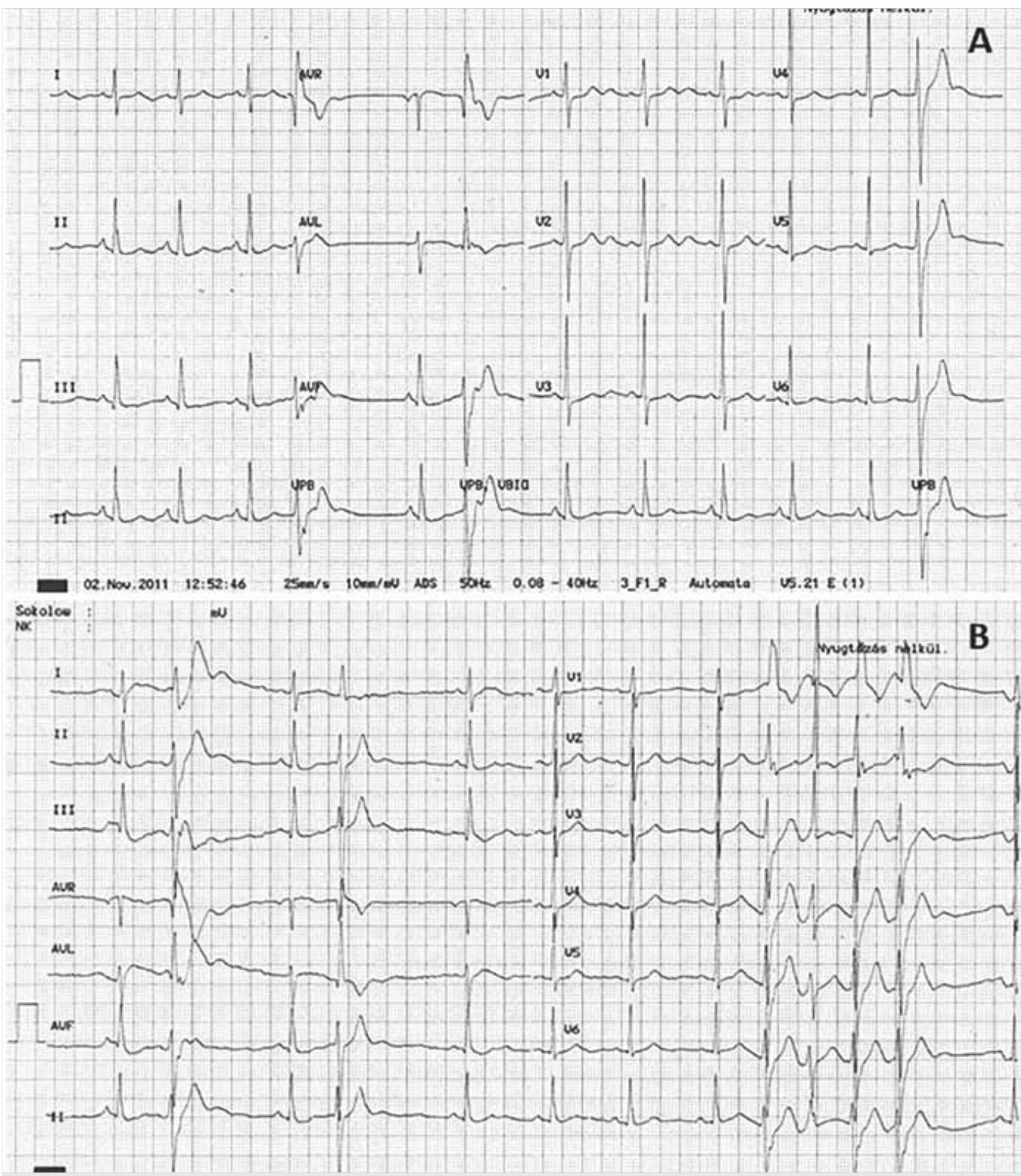

3. ÁBRA. EKG-eltérések Andersen-Tawil-szindrómában. A-panel: Enyhén megnyúlt OT-távolság (OT: 451 ms), $V_{1-3}$ elvezetésekben prominens U-hullám. 1-1 monomorf izolált VES. B-panel: Megnyúlt QT-távolság $\left(\mathrm{QT}_{\mathrm{c}}\right.$ : $\left.451 \mathrm{~ms}\right)$. Frekvens VES-lia, bigeminia, nem tartós kamrai tachycardia, bidirekcionális jelleggel

többje és az ATS-esetek mintegy $60 \%$-a diagnosztizálható. Bár az aritmia teher ATS-ben jellemzően nagy, de a CPVT-betegekkel ellentétben életveszélyes kamrai ritmuszavarba való átmenet nem jellemző (26). Míg a fizikai terhelés típusosan ritmuszavart indukál CPVT-s betegekben, addig a terhelés nem triggerel aritmiát ATS-betegekben, sőt egyes közlemények szerint a terhelés el is nyomhatja a ritmuszavart. Bár terheléses vizsgálat hasznos lehet a kivizsgálás során, a betegség neuromuszkuláris menifesztációi miatt elvégzése 


\begin{tabular}{|c|c|}
\hline Diagnózis valószínú & Tünet \\
\hline \multirow[b]{3}{*}{$\begin{array}{l}\text { A-eset (tünetek közül KETTŐ } \\
\text { megléte a betegnél) }\end{array}$} & Periodikus paralízis \\
\hline & $\begin{array}{l}\text { Tüneteket okozó aritmiák vagy megnagyobbodott U-hullámok, kamrai ektópiák, megnyúlt } \mathrm{QT}_{\mathrm{c}} \text { - } \\
\text { vagy } \mathrm{QU}_{\mathrm{c}} \text {-intervallum igazolása }\end{array}$ \\
\hline & $\begin{array}{l}\text { Jellemző arceltérések, fogászati eltérések, kis kéz- és lábméret mellett legalább két további } \\
\text { jellemző észlelése: } \\
\text { - alacsonyan álló fülek } \\
\text { - szélesen álló szemek } \\
\text { - kis mandibula } \\
\text { - kisujjat érintő clinodactylia } \\
\text { - 2-3 lábujjat érintő syndactylia }\end{array}$ \\
\hline B-eset & $\begin{array}{l}\text { Fenti tünetek közül EGY megléte, ha van még egy olyan elsőági családtag, akiben fenti klinika } \\
\text { kritériumok közül KETTŐ megtalálható }\end{array}$ \\
\hline
\end{tabular}

gyakran akadályokba ütközik. A 24 órás Holter-monitorizálás lehetővé teszi az aritmiateher meghatározását és összehasonlításul szolgálhat a gyógyszeres terápia hatásosságának leméréséhez.

\section{Diagnózis}

Az ATS diagnózisa a korábban részletezett típusos tünettan alapján klinikailag az 1. táblázatban részletezett kritériumok fennállása esetén valószínűsíthető (32). Az ATS diagnózisa A- vagy $B$-esetben állítható fel és/vagy a KCNJ2-gén genetikai módszerekkel kimutatott patogén mutációjának azonosítása esetén. A KCNJ2-gén relatíve kicsi gén, amely mindössze két exonból áll, amelyek közül a második exon tartalmazza a kódoló részt. Bár a $K C N J 2-g e ́ n$ része az új generációs alapú szekvenáláson alapuló diagnosztikus génpaneleknek, a gén kis mérete lehetővé teszi a gént érintő mutációk egyedi, kapilláris szekvenáláson alapuló vizsgálatát. Fentiek a Szegedi Tudományegyetem Kardiológiai Központjában elérhetők. Tekintettel arra, hogy a KCNJ2-gén eltérései a familiáris pitvarfibrilláció 9-es altípusát (OMIM 613980), illetve a rövid QT-szindróma 3-as altípusát (OMIM 609622) is okozzák, a gén eltérésének kimutatása önmagában nem diagnosztikus ATSre, de a típusos klinikai kép és a géneltérés együttes igazolása igen.

\section{Terápia}

Az ATS kezelése a legtöbb esetben egyénre szabott speciális tüneti terápiát jelent. Tekintettel arra, hogy nincsenek nagy elemszámú vizsgálatok a betegség kezelését illetően és a legtöbb terápia hatásossága mindössze esetbemutatások kapcsán került leírásra, így nincsenek szabványosított kezelési protokollok vagy irányelvek. A betegek tüneteinek enyhítése multidiszciplináris feladat, amely neurológusok, kardiológusok, gyermekgyógyászok együttmüködését igényli.

\section{Non-kardiális tünetek kezelése (32)}

A betegség domináló klinikai megjelenését jelentő periodikus paralízis kezelése a roham alatt észlelt káliumszinttől függ. Amennyiben a beteg hypokalaemiás, 15-30 percenként adott orális káliumkészítmény alkalmazásával javasolt a káliumszintet normalizálni. Tekintettel arra, hogy dysphagia jelenléte nem jellemző a rohamok alatt, az orális káliumpótlás a legbiztonságosabb. Amennyiben vénás káliumpótlásra kényszerülünk, az izotóniás sóoldat vagy glükózoldat helyett (mindkettő ronthatja az izomgyengeséget) 5\%-os mannizol adása javasolt. A szérum káliumszint és az EKG monitorizálása feltétlenül szükséges a káliumszupplementáció ideje alatt. A hyperkalaemiával társuló paralízis általában 60 percen belül spontán oldódik, amely meggyorsítható szénhidrátok fogyasztásával vagy folyamatos alacsony intenzitású fizikai aktivitással.

A hypokalaemiával társult paralízisek megelőzésében szerepe lehet a lassan felszívódó káliumkészítmények alkalmazásának, a szérum káliumszint „magas normál" tartományba emelése (>4 mEq/l) csökkentheti az esetlegesen megnyúlt QT-intervallumot és csökkentheti az LQT-asszociált ritmuszavarok kialakulásának veszélyét is. Tüneti terápiaként jó hatásúak lehetnek a karboanhidráz-bénítók (acetazolamid felnőtteknél 125$1000 \mathrm{mg} / \mathrm{nap}$, míg gyerekekben a dózis $5-10 \mathrm{mg} / \mathrm{kg} / \mathrm{nap}$ napi 2 adagban vagy dichlorphenamid 50-200 mg/1-2×/ nap). Amennyiben szívelégtelenség alakul ki és vízhajtó terápiát kellene alkalmazni, úgy javasolt a káliumkímélő vízhajtók adása.

\section{Kardiális tünetek kezelése}

Az ATS kardiális manifesztációjára jellemző gyakori VES-lia nehezen befolyásolható gyógyszeres kezeléssel $(33,34)$. Az acetazolamid, amely hatásos lehet a periodikus paralízis kezelésében, nincs hatással a kamraaritmiákra. A CPVT-től eltérően, az ATS-ben észlelt aritmiaformák nem tűnnek katecholamin szenzitívnek, amelyet a béta-blokkolók hatástalansága is igazol. A verapamil, amely egy esetben hatásos volt a bidirekcionális VT kezelésére (35), egy másik esetben torsade de pointes-t és syncope-t váltott ki (36). 
Nemrégen a flecainid kedvező terápiás hatását közölték ATS-ben $(30,36,37)$. Húsz család 36 tagjának utánkövetéses vizsgálatában is a számos alkalmazott gyógyszer vagy gyógyszer-kombináció közül a béta-blokkoló-flecainid kombináció volt a leghatásosabb az aritmiateher csökkentése szempontjából, amely 6 beteg közül 5 betegnek csökkentette azt (38). Figyelembe véve, hogy a kamrai VES-lia tünetmentes az esetek többségében, kérdéses, hogy a flecainidet minden esetben alkalmazni kell-e. Jelenleg fleacainid kezelés elsővonalbeli terápiaként azokban az esetekben indikált, ahol a kamrafunkció csökkent, vagy ahol a tachycardiás epizódok nagy aránya ennek kialakulásának kifejezett veszélyét jelzi előre. Bár vannak arra utaló adatok, hogy a tachycardia teher flecainid alkalmazásával csökkenthető, de kérdéses, hogy ez a hirtelen szívhalál rizikót is csökkenti-e ATS-betegekben. Aritmiák kezelésében nem javasolt bizonyos antiaritmiás gyógyszerek használata (pl. lidocain, mexiletin, propafenon, kinidin). Az I. osztályba sorolható szerek súlyosbíthatják a neuromuszkuláris tüneteket. Ismert QT-nyújtó gyógyszerek alkalmazása szintén kerülendő. Az irodalomban közölt eddigi tapasztalatok szerint a frekvens VES-lia ablációja szinte kivétel nélkül sikertelen volt $(38,39)$, amely nem meglepő az aritmogén szubsztrát mindkét kamrát érintő szerteágazó jelenléte miatt és ennek megfelelően nem ajánlott.

Az ICD-implantáció indikációjának felállítása nagy körültekintetést igényel ATS-ben, tekintettel arra, hogy az ATS-ben észlelt aritmiák nagy része tünetmentes és spontán terminálódó. Utóbbi alapján a Holter-monitorizálás alatt megfigyelt jelentős aritmiateher önmagában nem indikáció ICD-implantáció szempontjából. ICD-implantáció indokolt szekunder prevenció céljából azon ATS-betegekben, akik abortált hirtelen szívhalált éltek át, és valószínüleg indokolt lehet azon ATS-betegekben, akikben balkamra-diszfunkció alakult ki (40). Azokban az ATS-betegekben, akikben gyógyszeres kezelés ellenére gyakori polimorf VT vagy gyakori syncope jelentkezik, az ICD-implantáció felvetődik, gondos megfontolás után, tekintettel ezen betegcsoport fiatal átlagéletkorára. A lassú, gyakran magától szűnő kamrai tachycardiás rohamok jelentkezése miatt fontos a hosszú VT-detekció programozása.

\section{Köszönetnyilvánítás}

A munka a „Ritka betegségek patogenezisének kutatása, új diagnosztikai és terápiás eljárásokat megalapozó fejlesztések" (GINOP-2.3.2-15-2016-00039) és a „Életet veSzélyezTető Akut megbetegedések súlYossági és hALálozási mutatólnak jaVítása transzlációs orvostudományi mEgközelítésben - STAY ALIVE" (GINOP-2.3.2-15-2016-00048) támogatásával készült.

\section{Irodalom}

1. Elliott PM, Anastasakis A, Borger MA, et al. 2014 ESC Guidelines on diagnosis and management of hypertrophic cardiomyopathy: the Task Force for the Diagnosis and Management of Hypertrophic
Cardiomyopathy of the European Society of Cardiology (ESC). Eur Heart J 2014; 35: 2733-2779. doi: 10.1093/eurheartj/ehu284

2. Toth $T$, Nagy $V$, Faludi $R$, et al. The GIn1233ter mutation of the myosin binding protein $\mathrm{C}$ gene: Causative mutation or innocent polymorphism in patients with hypertrophic cardiomyopathy? Int J Cardiol 2011; 153(2): 216-9. doi: 10.1016/j.ijcard.2011.09.062

3. Orosz A, Baczko I, Nagy V, et al. Short-term beat-to-beat variability of the QT interval is increased and correlates with parameters of left ventricular hypertrophy in patients with hypertrophic cardiomyopathy. Can J Physiol Pharmacol 2015; 93(9): 765-72. doi: 10.1139/ cjpp-2014-0526

4. Csanyi B, Popoiu A, Hategan L, et al. Identification of two novel LAMP2 gene mutations in Danon disease. Can J Cardiol 2016; 32(11): 1355.e23-1355.e30. doi: 10.1016/j.cjca.2016.02.071

5. Csányi B, Hategan L, Nagy V, et al. Identification of a Novel GLA Gene Mutation, p.lle239Met, in Fabry Disease with a Predominant Cardiac Phenotype. Int Heart J 2017; 58(3): 454-458. doi: 10.1536/ ihj.16-361

6. Csanády M, Kiss Z. Az elektrokardiogram QT-távolságának örökletes megnyúltsága, veleszületett süketség nélkül (RomanoWard-syndroma). Orv Hetil 1972; 47: 2840-2843.

7. Sepp R, Hategan L, Bácsi A, et al. Timothy Syndrome 1 Genotype without Syndactyly and Major Extracardiac Manifestations. Am J Med Genet A 2017; 173(3): 784-789. doi: 10.1002/ajmg.a.38084

8. Hategan L, Csányi B, Ördög B, et al. A novel 'splice site' HCN4 gene mutation, c.1737+1 G>T, causes familial bradycardia, reduced heart rate response, impaired chronotropic competence and increased short-term heart rate variability. Int J Cardiol 2017; 241: 364372. doi: 10.1016/j.jicard.2017.04.058. E

9. Klein R, Ganelin R, Marks JF, et al. Periodic paralysis with cardiac arrhythmia. J Pediatr 1963; 62: 371-85. doi: 10.1016/S00223476(63)80134-1

10. Andersen ED, Krasilnikoff PA, Overvad H. Intermittent muscular weakness, extrasystoles and multiple developmental anomalies. A new syndrome? Acta Paediatr Scand 1971; 60: 559-64. doi: 10.1111/ j.1651-2227.1971.tb06990.x

11. Tawil R, Ptáček LJ, Pavlakis SG, et al. Andersen's syndrome: potassium-sensitive periodic paralysis, ventricular ectopy and dysmorphic features. Ann Neurol 1994; 35: 326-30. doi: 10.1002/ ana.410350313

12. Donaldson MR, Jensen JL, Tristani-Firouzi M, et al. PIP2 binding residues of Kir2.1 are common targets of mutations causing Andersen syndrome. Neurology 2003; 60: 1811-6. doi: 10.1212/01. WNL.0000072261.14060.47

13. Rajakulendran S, Tan SV, Hanna MG Muscle weakness, palpitations and a small chin: the Andersen-Tawil syndrome. Pract Neurol 2010; 10(4): 227-31. doi: 10.1136/jnnp.2010.217794.

14. Plaster NM, Tawil R, Tristani-Firouzi M, et al. Mutations in Kir2.1 cause the developmental and episodic electrical phenotypes of Andersen's syndrome. Cell 2001; 105: 511-9. doi: 10.1016/S00928674(01)00342-7

15. Raab-GrahamKF, Radeke CM, Vandenberg CA Molecular cloning and expression of a human heart inward rectifier potassium channel. Neuroreport 1994; 5: 2501-5. doi: 10.1097/00001756199412000-00024

16. Gaborit N, Le Bouter S, Szuts V, et al. Regional and tissue specific transcript signatures of ion channel genes in the non-diseased human heart. J Physiol 2007; 582(Pt 2): 675-93. doi: 10.1113/jphysiol.2006.126714

17. Kimura H, Zhou J, Kawamura M, et al. Phenotype variability in patients carrying KCNJ2 mutations. Circ Cardiovasc Genet 2012; 5(3): 344-53. doi: 10.1161/CIRCGENETICS.111.962316

18. Hibino $\mathrm{H}$, Inanobe $A$, Furutani $\mathrm{K}$, et al. Inwardly rectifying potassium channels: their structure, function, and physiological roles. Physiol Rev 2010; 90(1): 291-366. doi: 10.1152/physrev.00021.2009.

19. Ballester LY, Benson DW, Wong B, et al. Trafficking-competent 
and trafficking defective KCNJ2 mutations in Andersen syndrome. Hum Mutat 2006; 27: 388-95.

20. Ördög B, Hategan L, Kovács M, et al. Identification and functional characterisation of a novel KCNJ2 mutation, Val302del, causing Andersen-Tawil syndrome. Can J Physiol Pharmacol 2015; 93(7): 569-75. doi: 10.1139/cjpp-2014-0527

21. Wang $\mathrm{H}$, Ma $\mathrm{Y}$, Huynh J, et al. Functional characterization of KCNJ2 missense variants identified in patients with Andersen-Tawi Syndrome. J Am Coll Cardiol 2012; 59(Suppl.): E718 doi: 10.1016/ S0735-1097(12)60719-0

22. Yoon G, Oberoi S, Tristani-Firouzi M, et al. Andersen-Tawil syndrome: prospective cohort analysis and expansion of the phenotype. Am J Med Genet A 2006; 140: 312-21. doi: 10.1002/ajmg.a.31092

23. Child ND, Cleland JC, Roxburgh RH. Andersen-Tawil syndrome presenting as a fixed myopathy. Muscle Nerve 2013; 48(4): 623. doi: 10.1002 /mus. 23872

24. Yoon G, Quitania L, Kramer JH, et al. Andersen-Tawil syndrome: definition of a neurocognitive phenotype. Neurology 2006; 66 : 1703-10. doi: 10.1212/01.wnl.0000218214.64942.64

25. Tristani-Firouzi M, Jensen JL, Donaldson MR, et al. Functional and clinical characterization of KCNJ2 mutations associated with LQT7 (Andersen syndrome). J Clin Invest 2002; 110: 381-8. doi: 10.1172/jci15183

26. Zhang L, Benson DW, Tristani-Firouzi M, et al. Electrocardiographic features in Andersen-Tawil syndrome patients with KCNJ2 mutations: characteristic $\mathrm{T}-\mathrm{U}$-wave patterns predict the $\mathrm{KCNJ} 2$ genotype. Circulation 2005; 111: 2720-2726. doi: 10.1161/CIRCULATIONAHA.104.472498

27. Piccini J, Zaas A Cases from the Osler medical service at Johns Hopkins University. Digitalis toxicity with bidirectional ventricular tachycardia. Am J Med 2003; 115: 70-71. doi: 10.1016/s00029343(03)00331-0

28. Priori SG, Napolitano $\mathrm{C}$, Tiso $\mathrm{N}$, et al. Mutations in the cardiac ryanodine receptor gene (hRyR2) underlie catecholaminergic polymorphic ventricular tachycardia. Circulation 2001; 103: 196-200 doi: 10.1161/01.cir.103.2.196

29. Schoonderwoerd BA, Wiesfeld AC, Wilde AA, et al. A family with Andersen-Tawil syndrome and dilated cardiomyopathy. Heart Rhythm 2006; 11: 1346-50. doi: 10.1016/j.hrthm.2006.07.021

30. Pellizzón OA, Kalaizich L, Ptácek LJ et al. Flecainide suppresses bidirectional ventricular tachycardia and reverses tachycardia-induced cardiomyopathy in Andersen-Tawil syndrome. J Cardiovasc Electrophysiol 2008; 1: 95-7. doi: 10.1111/j.1540-8167.2007.00910.x 31. Rezazadeh S, Guo J, Duff HJ, et al. Reversible dilated cardiomyopathy caused by a high burden of ventricular arrhythmias in Andersen-Tawil syndrome. Can J Cardiol 2016; 12: 1576.e15-1576. e18. doi: 10.1016/j.cjca.2016.07.587

32. Veerapandiyan A, Statland JM, Tawil R. Andersen-Tawil Syndrome. 2004 Nov 22 [Updated 2018 Jun 7]. In: Adam MP, Ardinger HH, Pagon RA, et al. editors. GeneReviews ${ }^{\circledR}$ [Internet]. Seattle (WA): University of Washington, Seattle; 1993-2019.

33. Chun TU, Epstein MR, Dick M $2^{\text {nd }}$, et al. Polymorphic ventricular tachycardia and KCNJ2 mutations. Heart Rhythm 2004; 1(2): 23541. doi: 10.1016/j.hrthm.2004.02.017

34. Tristani-Firouzi M Polymorphic ventricular tachycardia associated with mutations in KCNJ2. Heart Rhythm 1: 242-243 doi: 10.1016/j.hrthm.2004.03.060

35. Kannankeril PJ, Roden DM, Fish FA Suppression of bidirectional ventricular tachycardia and unmasking of prolonged QT interval with verapamil in Andersen's syndrome. J Cardiovasc Electrophysiol 2004; 15(1): 119. doi: 10.1046/j.1540-8167.2004.03369.x

36. Bokenkamp R, Wilde AA, Schalij MJ, et al. Flecainide for recurrent malignant ventricular arrhythmias in two siblings with Andersen-Tawil syndrome. Heart Rhythm 2006; 4: 508-511 doi: 10.1016/j. hrthm.2006.12.031

37. Statland JM, Fontaine B, Hanna MG, et al. Review of the Diagnosis and Treatment of Periodic Paralysis. Muscle Nerve 2018; 57(4): 522-530. doi: 10.1002/mus.26009

38. Delannoy E, Sacher F, Maury P, Mabo P, Mansourati J, Magnin I et al. Cardiac characteristics and long-term outcome in Andersen-Tawil syndrome patients related to KCNJ2 mutation. Europace 2013; 15: 1805-11.

39. Manlio F. Márquez, Santiago Nava, Jorge Gómez, Luis Colín, Pedro Iturralde Márquez MF, Nava S, Gómez J, Colín L, Iturralde P. Lack of efficacy of radiofrequency catheter ablation in AndersenTawil syndrome: are we targeting the right spot? EP Europace 2014 16: 1697-1698. doi.org/10.1093/europace/eut428

40. Wilde AA. Andersen-Tawil syndrome, scarier for the doctor than for the patient? Who, when, and how to treat. Europace 2013; 15 : 1690-2. doi: 10.1093/europace/eut326 